\title{
TEMELJNO ŠOLANJE ČASTNIKOV V DRŽAVAH EVROPSKE UNIJE - ISKANJE ODGOVOROV NA SODOBNE ZAHTEVE
}

\author{
BASIC OFFICER TRAINING IN EUROPEAN \\ UNION COUNTRIES - SEEKING ANSWERS \\ TO CONTEMPORARY REQUIREMENTS
}

Povzetek V razpravah glede prihodnjega šolanja častnikov v Sloveniji je pomembno tudi preučevanje modelov v tujini in sodobnih problemov na tem področju. V prispevku so na kratko prikazani izzivi na področju temeljnega šolanja častnikov, predvsem z vidika razmerja med usposabljanjem za konkretne naloge in širše usmerjenim izobraževanjem. Kakovost izobraževanja je pomembna ne le za vojaško učinkovitost, temveč tudi za odnos vojske s civilnimi strukturami v državi in z mednarodnim okoljem. Prikazane so temeljne poteze šolanja častnikov v državah EU. Proces šolanja sestavljata dve medsebojno povezani komponenti: univerzitetno izobraževanje in poklicno usposabljanje. Sicer pa šolanje častnikov ostaja le pristojnost držav in v državah EU najdemo zelo različne modele. Temeljno šolanje častnikov v Sloveniji se glede glavnih sestavin ne razlikuje bistveno od prakse v večini držav EU, vendar bo $\mathrm{v}$ prihodnje treba odgovoriti na nekatera vprašanja, predvsem glede razvoja univerzitetnega izobraževanja. Prihodnji razvoj šolanja častnikov bo moral slediti praksi evropskih držav predvsem na vsebinskem področju. Način organiziranja pa je smiselno prilagoditi lastnim potrebam in zmožnostim.

Ključne Vojaško izobraževanje in usposabljanje, vojaška profesija, šolanje častnikov, besede Evropska unija, vojska in družba.

Abstract In the context of discussion about future officer education in Slovenia, it is important to study the current educational models in foreign countries and the contemporary problems in this area. The article briefly depicts challenges of basic officer education mainly from the viewpoint of relations between specific-purpose training and more broadly oriented education. The quality of education is important not only for military efficiency but also for military's relations with national civil structures and international environment. The article illustrates basic features of officer education in EU member states. The educational process consists of two interlinked parts: academic 
education and vocational training. Officer education is the sole responsibility of EU member states, and they practise very different models. Concerning its essential parts, officer education in Slovenia does not differ significantly from that of most EU members. However, it will be necessary to address some open questions, primarily those concerning the academic part of education. The future development of officer education should follow the patterns emerging in European states, first of all regarding educational content. However, it makes sense to adapt its organisational characteristics to our own needs and abilities.

Key words Military education and training, military profession, European Union, officer education, military and society.

Uvod V Sloveniji smo v zadnjih dveh desetletjih vzpostavili lasten model šolanja častnikov, hkrati pa potekajo tudi razprave o ustreznosti tega modela in morebitnih spremembah. ${ }^{1} \mathrm{~V}$ dokumentih najdemo usmeritve, da naj bi šolanje postalo čim bolj primerljivo z modeli šolanja v tujini. Tako v Vojaški doktrini (2006, str. 35) ugotavljamo, da je sistem izobraževanja in usposabljanja »primerljiv s sistemi vojska v zavezništvu«. V veljavnem SOPR ${ }^{2}$ je zapisano, da bodo postopno »upoštevani merila in standardi, ki veljajo v javnem izobraževalnem sistemu in mednarodnem okolju« (str. 39). Ne smemo zanemariti dejstva, da članstvo države v Natu in EU od vojske zahteva tudi sposobnosti za delovanje v mednarodnih vojaških strukturah in zato tudi kompetence častnikov, ki so primerljive s tujimi. Dodati je treba tudi, da so zahodne vojske v procesu ene najbolj intenzivnih transformacij v novejši zgodovini, zato so danes pred številnimi izzivi na področju izobraževanja častnikov.

Potrebe po mednarodni primerljivosti se pri nas zavedamo, vendar gre pri razpravah o izobraževanju pogosto za nezadostno poznavanje razvojnih trendov in dilem, s katerimi se srečujejo v zahodnih državah. V prispevku bomo poskušali prikazati temeljne dileme glede prilagajanja šolanja častnikov sodobnim zahtevam in različne pristope k šolanju v državah članicah EU. Prikaz bo omejen na raven temeljnega šolanja častnikov kopenske vojske, ki ga na splošno razumemo kot tisto fazo šolanja, ki se zaključi s pridobitvijo prvega častniškega čina. V zaključnem delu prispevka bomo prevladujočo prakso evropskih držav poskušali primerjati s slovenskim modelom šolanja častnikov in predstaviti nekaj razmislekov glede šolanja $\mathrm{v}$ prihodnje.

\footnotetext{
Uporabljamo izraz šolanje, ki združuje izobraževanje in usposabljanje ter ga razumemo kot formalno organizirano obliko v primerjavi s samoizobraževanjem.

2 Srednjeročni obrambni program Republike Slovenije, 17. 2. 2016, Vlada RS.
} 


\section{1 ŠOLANJE ČASTNIKOV - IZOBRAŽEVANJE IN/ALI USPOSABLJANJE}

$\mathrm{Na}$ splošno v sodobnem svetu velja, da mora šolanje častnikov zagotoviti dovolj široko izobrazbo in sposobnost nadgrajevanja znanja, hkrati pa bodoče častnike pripraviti tudi za učinkovito delo po prihodu na častniško dolžnost. Obsegati mora torej teoretično in veščinsko komponento. V sodobnih vojskah proces izobraževanja in usposabljanja (angl. education and training) pogosto obravnavajo kot celovit proces priprave kadra. Ker pa so častniki nosilci vojaške profesije, vsako profesijo pa opredeljuje specifični nabor teoretičnega znanja, je zelo pomembna prav izobraževalna komponenta. Foot (2006, str. 14) meni, da se meje med izobraževanjem in usposabljanjem (in tudi definicije) prekrivajo. Vendar pa na teoretični ravni značilnosti ene in druge komponente pogosto metaforično označujejo s špartanskim in atenskim pristopom k šolanju častnikov. Špartanski pristop je mogoče enačiti z usposabljanjem; zagotavlja poznavanje znanih dejstev in temelji na vrednotah, kot so disciplina, samožrtvovanje, vrednotenje tehnologije, patriotizem, čast in herojstvo. Atenski pristop predstavlja izobraževanje; zagotavlja orodja, s katerimi se je mogoče spopadati z neznanim, in temelji na vrednotah, kot so učenje, kreativno in kritično razmišljanje, vrednotenje filozofije in zgodovine, medkulturno razumevanje ter postherojstvo. ${ }^{3}$ Šolanje častnikov je vedno zmes obeh pristopov. Z višjo ravnjo izobraževanja med kariero je vse bolj pomemben drugi pristop. Vendar tudi sodobne zahteve, glede na vedno bolj neznane izzive, s katerimi se bodo spoprijemali častniki, vedno bolj zahtevajo atenski pristop (prav tam, str. 15).

Razumevanje procesov izobraževanja in usposabljanja ali atenskih in špartanskih značilnosti šolanja častnikov je zelo pomembno zaradi spremenjenih zahtev, ki se postavljajo pred častniško profesijo. V teoriji najdemo različne opredelitve obeh procesov, vendar je razlikovanje med izobraževanjem in usposabljanjem pri vseh precej podobno (tabela 1).

Podobno Paile (2011, str. 17) navaja razlikovanje med razumevanjem častnikov kot »elitnih vojakov« ali »špartancev« in kot »strategov« ali »atencev«. 
Tabela 1:

Razumevanje izobraževanja

in usposabljanja na vojaškem področju

\begin{tabular}{|l|l|}
\hline Izobraževanje (Education) & Usposabljanje (Training) \\
\hline \multicolumn{2}{|l|}{ International Military and Defence Encyclopedia, 1993, str. 804-5 } \\
\hline $\begin{array}{l}\text { Vojaško izobraževanje je sistematično poučevanje } \\
\text { posameznikov, ki povečuje njihovo poznavanje } \\
\text { znanosti in veščine vojskovanja. Izobraževanje je } \\
\text { usmerjeno na posameznike. }\end{array}$ & $\begin{array}{l}\text { Usposabljanje je poučevanje osebja za krepitev } \\
\text { in urjenje ene ali več enot za krepitev bojne } \\
\text { sposobnosti. Usmerjeno je bodisi na posameznika } \\
\text { ali enoto. }\end{array}$ \\
\hline
\end{tabular}

Žabkar in Svete, 2008, str. 188

Izobraževanje se nanaša na načrtno poučevanje posameznikov na področjih, s katerimi poglabljajo znanje iz domene znanosti in veščine vojskovanja. Prispeva k pridobivanju znanj in razumevanju vojaških procesov, kar je pogoj za presojo razmer in sprejemanje racionalnih odločitev. Je teoretsko naravnano (vključuje opisovanje, klasificiranje, interpretacijo in predvidevanje). Povezano je s posameznikom.

Vojaško usposabljanje je proces pripravljanja posameznikov ali enot na uspešno opravljanje konkretnih nalog v vojni. Razvijajo se praktično akcijsko znanje in veščine. Je večdimenzionalno, poleg posameznika lahko zajema tudi štabe, enote in skupine.

Education and Training Directive - Bi-SC 75-2, Nato, 2013, str. 9

Sistematično poučevanje posameznikov $v$ predmetih, ki povečuje njihovo znanje in spretnosti ter razvija kompetence.
Individualno usposabljanje: vse aktivnosti poučevanja, ki zagotavljajo znanje, spretnosti in kompetence, potrebne za opravljanje dodeljene dolžnosti.

Kolektivno usposabljanje: urjenje postopkov in praktično izvajanje doktrine, načrtov in postopkov za doseganje in ohranjanje taktičnih, operativnih in strateških zmogljivosti.

Officer Professional Military Education Policy, (Enc. A, e), ZDA, 2015

Izobraževanje večinoma poteka na kognitivnem področju in razvija širino in različnost pogledov, sposobnost kritične analize in abstraktnega razmišljanja v razmerah nejasnosti in negotovosti ter inovativnega razmišljanja, posebej ob kompleksnih in nelinearnih problemih.
Usposabljanje je usmerjeno predvsem na psihomotorično področje, in sicer s poučevanjem osebja za povečanje sposobnosti izvajanja konkretnih funkcij in nalog.

Doktrina vojaškega izobraževanja in usposabljanja, Slovenija, 2013, str. 7

Pri vojaškem izobraževanju je pomembno s teoretičnim znanjem in spoznavanjem etičnih načel in standardov, ki oblikujejo dobrega vojaka, utrjevati integriteto posameznika.
Pri vojaškem usposabljanju sta v ospredju razvijanje praktičnega znanja, veščin in postopkov ravnanja, pridobljenega predvsem z urjenjem, ter oblikovanje posebnih sposobnosti, značajskih in moralnih lastnosti.

MacAllister, navedno v McCausland in Martin, 2001

Izobraževanje je usmerjeno k bolj splošnemu in abstraktnemu znanju, ki je lahko ali pa tudi ni povezano s specifično nalogo in aktivnostjo.

Usposabljanje je usmerjeno k razvoju in sposobnosti opravljanja konkretnih nalog ali spretnosti. 
Iz navedenih pogledov na izobraževanje in usposabljanje je mogoče razbrati, da gre za razlike tako glede vsebine kot ciljev obeh procesov. Izobraževanje razumemo kot dejavnost, usmerjeno $\mathrm{v}$ domeno teorije in bolj abstraktnega razmišljanja, usposabljanje pa je bolj usmerjeno na konkretne sposobnosti za neko delo ali funkcijo oziroma na praktične postopke. Izobraževanje je usmerjeno v razvoj sposobnosti za reševanje problemov, usposabljanje pa v izvajanje rutinskih postopkov. Posledično izobraževanje razvija sposobnosti za reševanje novih, nepredvidljivih problemov, usposabljanje pa sposobnosti za odzivanje $\mathrm{v}$ vnaprej predvidenih situacijah. Izobraževanje je vedno usmerjeno k posamezniku, usposabljanje pa k posamezniku ali skupini oziroma enoti.

$\mathrm{Na}$ splošno različne poklicne dejavnosti zahtevajo različen obseg predhodnega izobraževanja ali usposabljanja oziroma je razmerje med tema sestavinama različno. Tudi za vojaške poklice lahko trdimo enako, vojaki se predvsem usposabljajo, tako individualno kot skupinsko, za častniški kader pa je pomembno, da se ob usposabljanju za opravljanje dolžnosti zagotovi tudi ustrezno izobraževanje. Pri šolanju častnikov gre za povezanost obeh procesov, jasno ločnico med njima pa je težko postaviti. Nekateri avtorji tudi menijo, da je usposabljanje del izobraževanja. Kramar (1996, str. 16) trdi, da »usposabljanje ni celoten proces pridobivanja znanja, razvijanja spretnosti, sposobnosti in navad vojaškega delovanja, temveč pomembna sestavina procesa izobraževanja in usposabljanja«. Danes je vojaško osebje pravzaprav vse bolj soočeno s potrebo po izobraževanju in ne le usposabljanju.

Pravzaprav se vse profesije, ne le vojaška, srečujejo s problemom razmerja med širšim, bolj abstraktnim izobraževanjem in usposabljanjem za konkretno delo. Kot meni Svetlik, ki ga navaja Kotnik (2012, str. 21), se danes profesije spoprijemajo s hitrimi spremembami, zaradi katerih je vse manj mogoče in smiselno nove pripadnike usposabljati za opravljanje konkretnih profesionalnih nalog v začetnem izobraževanju. Namesto tega predlaga, naj bo izobraževanje začetnikov čim bolj usmerjeno v pridobivanje splošnih in široko uporabnih sposobnosti in znanja, kar bo zagotavljalo dobro podlago za poznejše sprotno prilagajanje spreminjajočemu se profesionalnemu delu.

Munnik (2012, str. 461) opozarja, da se danes večina vojaških institucij ukvarja z vprašanjem, koliko je v izobraževanje vojaškega osebja treba vključevati akademski pristop. Še posebej po hladni vojni je v razpravah o šolanju častnikov vse bolj prisotno prepričanje, da ti potrebujejo široko izobrazbo. Tradicionalno je veljalo, da mora temeljno šolanje častnikov zagotoviti sposobnost opravljanja prve dolžnosti v častniški karieri, širšo in bolj strateško usmerjeno izobrazbo pa častniki pridobivajo na višjih ravneh šolanja $v$ času svoje kariere ${ }^{4}$ Danes se tudi na področju vojaške profesije pojavlja vse več razprav o tem, da je treba častnikom že v začetnih fazah

4 Pri tem gre za različne oblike štabnega in generalštabnega šolanja, ki so pogoj za doseganje višjega čina oziroma za delo na višjih poveljniških ravneh. 
šolanja zagotoviti bolj široko in abstraktno znanje, kar pa pomeni spremembo razmerja med izobraževanjem in usposabljanjem.

Kotnik (2012, str. 21) meni, da vojaškega osebja »zgolj urjenje in usposabljanje, brez ustreznega izobraževanja, dolgoročno gledano ne bosta več zadovoljivo opremili s potrebnimi kompetencami za izvedbo nalog v vse bolj zapletenem in za napake zelo občutljivem okolju«. Podobno Johnson-Freese (2013, str. 204-5) meni, da je treba, če želimo doseči premik k bolj transformativnemu izobraževanju, ${ }^{5}$ najprej sprejeti dejstvo, da je razlika med izobraževanjem in usposabljanjem, nato pa se od nagnjenosti k usposabljanju preusmeriti k prevladi izobraževanja. Poklicno vojaško izobraževanje častnikov, meni, mora preseči usmerjenost le na usposabljanje, ki je sicer inherentno njegov del:

Združeno vojaško profesionalno izobraževanje $(J P M E)^{6}$ presega usposabljanje s tem, ko dodaja razumevanje konteksta, kar omogoča optimalno usposabljanje. Enako, če ne celo bolj pomembna je pedagoška razlika med usposabljanjem in izobraževanjem. Uspešnost programov usposabljanja je lahko meriti, ker se učimo o pravih in napačnih metodah in odgovorih. Ko gre za izobraževanje, pa je merjenje uspeha manj jasno in težje, ker se izobraževanje umerja na vprašanje, kako razmišljati, ne kaj razmišljati, zahteva čas za študij in razmišljanje in pogosto ne nudi pravih ali napačnih odgovorov [poudarek je izviren].

Šolanje častnikov je po mnenju iste avtorice tudi sicer treba čim bolj približati standardom, ki veljajo v civilnem šolstvu. Pri tem je treba zagotavljati: 1) akademsko svobodo v smislu dopuščanja obravnave različnih pogledov $\mathrm{v}$ izobraževalnem procesu; 2) kakovosten predavateljski kader, ki posreduje ustrezna profesionalna znanja in izkušnje in je sposoben v poučevanje vključevati tudi transformativne izzive; 3) relevantne učne programe.

Paile (2011, str. 11) v svoji analizi šolanja častnikov v evropskih državah opozarja na pomen doseganja fleksibilnosti in širine razmišljanja že med šolanjem. Za to si je treba prizadevati že kolikor je mogoče zgodaj v procesu šolanja, saj se bodo mnogi častniki že v začetku svoje kariere srečali z mednarodnimi razsežnostmi svojega poklica. Tudi ameriška avtorja McCausland in Martin (2001) ugotavljata, da se že mlajši častniki pogosto znajdejo v nejasnih in kompleksnih razmerah delovanja, ki zahtevajo več intelekta, pobude in sposobnosti vodenja, kot je to veljalo v hladni vojni. V resnici se zmanjšujejo razlike med taktično, operativno in strateško ravnjo vojskovanja. Takšne razmere lahko odkrijemo v delovanju, ki ga v Natu imenujemo »operacije kriznega odzivanja«, vedno bolj verjetne pa so tudi z vse večjo prisotnostjo hibridnih oblik vojskovanja. To pomeni, da bodo že častniki na nižji ravni morali sprejemati odločitve, ki imajo operativne ali strateške posledice.

\footnotetext{
5 Po mnenju avtorice je transformativno izobraževanje usmerjeno $v$ širjenje znanja in pogledov posameznika za doseganje večje »intelektualne agilnosti«.

${ }^{6}$ Joint Professional Military Education.
} 
Temu je treba prilagoditi tudi šolanje častnikov že na temeljni ravni, kar pomeni, da jih je treba opremiti z abstraktnim profesionalnim znanjem, ki ga lahko uporabijo v določeni situaciji. Častnikom je treba zagotoviti »razumevanje temeljnih strateških konceptov že bolj zgodaj v njihovi karieri« (prav tam: 19). Takšne priprave zahtevajo izobraževanje na področjih zgodovine, političnih znanosti, ekonomije, regionalnih in kulturoloških študij, etike in varnostnih zadev (prav tam: 22). Menita, da je široko teoretično izobrazbo častnikom treba zagotavljati že od začetka šolanja, to pa je podlaga, na kateri se gradi njihovo nadaljnje izobraževanje med kariero. Ocenjujeta, da je praksa, ko poskušajo častnike šele po 20 letih kariere na desetmesečnem najvišjem vojaškem šolanju preobraziti iz »taktikov in operativcev v stratege«, nezadostna in neustrezna, če želimo, da bodo častniki sposobni ustrezno opravljati svoje dolžnosti (prav tam: 24).

Ustrezna izobrazba častnikov ni pomembna le za kakovostno izvajanje neposrednih nalog vojske v zagotavljanju varnosti in obrambe. Povezana je tudi z obstojem vojske kot družbene institucije in njeno vlogo v družbenem okolju. Foot (2006, str. 18) navaja, da ustrezno izobraževanje vpliva na preprečevanje teh pojavov:

- upadanje kakovosti »vojaškega nasveta«, ki ga vojska zagotavlja političnemu vodstvu, ter hkrati poslabšanje podobe o učinkovitosti vojske in povečevanje prepada med njo in civilnim uradništvom na obrambnih in zunanjih ministrstvih;

- zmanjševanje primerljivosti s častniškim zborom zavezniških držav in posledično manj možnosti za pridobivanje poveljniških dolžnosti v tujini;

- povečanje izoliranosti vojske $\mathrm{v}$ družbi, slabšanje njene podobe ter nižanje standardov za vstop v častniški poklic;

- frustracije sposobnih častnikov, ki se kažejo v težnji po predčasnem odhodu iz vojske in zmanjšanju njihove motivacije za poučevanje v vojski.

Hkrati Foot (2006, str. 19) meni, da izobraževanje ne sme temeljiti le na zahtevah dolžnosti, ki jo bodo častniki opravljali neposredno po nekem šolanju, temveč mora zagotavljati višjo stopnjo profesionalnosti in intelektualni razvoj. Navedena razmišljanja kažejo na širok pomen izobraževanja častnikov; poleg zagotavljanja vojaške učinkovitosti je to pomembno tudi za odnos vojske s političnimi strukturami ter civilno družbo v lastni državi in z zavezniškimi ali partnerskimi vojskami v tujini oziroma za status in ugled vojske doma in v tujini.

\section{MODELI ŠOLANJA ČASTNIKOV V EVROPSKIH DRŽAVAH}

Izobraževanje in poklicno delo častnikov je tudi $\mathrm{v}$ današnjem času trdno vpeto $\mathrm{V}$ državne okvire. V tem se razlikuje od večine drugih profesij in poklicev, pri katerih se povečuje mobilnost na področju izobraževanja in zaposlovanja. Pripadniki številnih profesij danes najdejo zaposlitev v drugih državah, ne v tistih, v katerih so pridobili 
svojo izobrazbo. V EU je takih sedem odstotkov od vseh zaposlenih. ${ }^{7}$ Taka mobilnost je vse bolj značilna tudi za visoko izobražen kader, ki se seli praviloma v države, ki ponujajo bolj perspektivno okolje. V zvezi z mobilnostjo visoko izobraženega kadra pogosto govorimo o begu možganov, ki tudi v Sloveniji ni nepoznan. Vendar pa omenjeni trend ne velja za vojaško profesijo. Čeprav ta spada med tiste, ki so danes najbolj odprte $»$ mednarodnim realnostim $\ll^{8}$ (Paile, 2011, str. 11), se častniki izobražujejo v državi, v kateri opravljajo tudi svoj poklic, v času kariere pa nimajo možnosti mobilnosti med državami. V redkih primerih najdemo odstopanja, ki pa so posledica izjemnih situacij. ${ }^{9}$

Za častniško profesijo je značilno, da ima vsaka država izključno odgovornost za šolanje svojih častnikov. V primerjavi z drugimi profesijami zelo načrtno skrbijo za pridobivanje in njihovo izobraževanje. Načini in vsebine šolanja so specifični za vsako državo, opredeljeni s potrebami, kot jih država definira, s tradicijo, kulturo, vrednotami, značilnostmi vojaške organizacije, vojaško doktrino idr. Šolanje praviloma poteka v specializiranih ustanovah (fakultetah, akademijah), ki so del vojaških oziroma obrambnih struktur države ali pa so z njimi tesno povezane. Ponekod izobraževanje častnikov poteka tudi v povezavi s civilnimi izobraževalnimi institucijami, vendar pa sta vloga in vpliv vojsk v izobraževanju častnikov odločilna. Vojska ni le »delodajalec« častniškemu kadru, ampak tudi oblikuje zahteve in izvaja izobraževalni proces častnikov; je hkrati njihov »preskrbovalec in uporabnik« (provider and end-user) (Paile, 2011, str. 30).

Ob siceršnji organizacijski in vsebinski raznolikosti šolanja častnikov v državah članicah EU so zelo redke primerjalne analize šolanja, na sploh pa je to redko predmet bolj celovite teoretične obravnave. Nekoliko več pozornosti so temu začeli posvečati v okviru zamisli o projektu Vojaški Erasmus (Military Erasmus), ki naj bi okrepil izmenjavo šolajočih se in učiteljev med vojaškimi šolami članic EU. Zato se je začela izmenjava informacij, na podlagi katere je leta 2011 nastala publikacija »Compendium of the European Military Officers Basic Education« (urednik S. Paile). Gre za analizo temeljnih značilnosti šolanja častnikov in je prvi tovrstni pregled na ravni EU.

Primerjava uveljavljenih modelov pokaže na različne oblike temeljnega šolanja častnikov. Medtem ko je šolanje povsod sestavni del pridobivanja častniškega

\footnotetext{
Po podatkih EUROSTAT-a je bilo leta 2012 v EU 15,2 milijona ljudi zaposlenih zunaj države rojstva. Od tega jih 6,6 milijona prihaja iz druge članice EU, 8,6 milijona pa iz države nečlanice. Vletih 2011 in 2012 je državo zaposlitve spremenilo en milijon ljudi. Največ prihodov so ugotovili v Veliki Britaniji, Nemčiji, Španiji, Franciji, Avstriji in Italiji. V primerjavi z letom 2010 gre za 6,5-odstotni porast zaposlitev v drugi državi. http:// ec.europa.eu/eurostat/statistics-explained/index.php/Archive:Labour_force_survey_overview_2012 (8. 7. 2016)

$\&$ Predvsem zaradi pogostega opravljanja dela v mednarodnem okolju in potrebe po sodelovanju s pripadniki drugih vojsk. Vojaške operacije so danes multilateralne in potekajo v okoljih, ki so bistveno drugačna od domačega okolja pripadnikov vojske.

9 Tako na primer med državami, vključenimi v analizo, Ciper, Luksemburg in Malta nimajo vojaških izobraževalnih institucij in častnike šolajo v tujini. Do izjem pride tudi pri razpadu in nastajanju novih držav, kot so na primer Sovjetska zveza, Jugoslavija in Nemška demokratična republika, v katerih so častniki vstopili v vojske novih ali drugih držav.
} 
kadra, je že odnos med šolanjem in pridobitvijo čina različen. Ponekod šolajoči se dobijo častniški čin že med šolanjem, drugje šele po zaključku (Paile, 2011, str. 17). Razlikujeta se tudi dolžina šolanja bodočih častnikov in stopnja zahtevane izobrazbe za podelitev častniškega čina. Vsi programi šolanja častnikov vsebujejo bolj splošne oziroma civilnim programom podobne vsebine (tehnične in družboslovne) in tudi bolj vojaško naravnane vsebine ter praktično usmerjeno usposabljanje za poklic častnika. Razmerje med temi vsebinami se v državah razlikuje.

Splošni trend v Evropi in na Zahodu je težnja za povečevanje »intelektualne legitimnosti« častnikov, ki je posledica spremenjenih nalog vojsk po koncu hladne vojne, pa tudi potrebe po zagotavljanju ustrezne izobrazbe, ki častnikom ob odhodu iz vojske omogoča zaposlovanje v civilni sferi (prav tam, str. 20). Skladno s tem se šolanje častnikov približuje značilnostim univerzitetnega izobraževanja, institucije, ki ga izvajajo, pa so podobne drugim univerzitetnim ustanovam. To vključuje tudi uveljavljanje načel Bolonjske deklaracije $\mathrm{v}$ delovanju vojaških izobraževalnih institucij.

Omenjena analiza je ponudila tudi analitični model, ki poskuša prikazati temeljne sestavine šolanja častnikov. Te so: a) razvoj sposobnosti voditeljstva - leadership; b) univerzitetno izobraževanje - academic education; c) poklicno usposabljanje vocational training (shema 1). Zagotavljanje sposobnosti voditeljstva je temeljni cilj izobraževanja in usposabljanja častnikov tako v fazi temeljnega kot nadaljevalnega šolanja, zato v analizi tudi ni obravnavano kot sestavina sama po sebi, je namreč rezultat šolanja in temeljna kompetenca častnikov. Voditeljstvo tudi ni nujno predmet, ki se poučuje v procesu šolanja; razvoj voditeljskih sposobnosti je v bistvu vpet $\mathrm{v}$ celoten proces izobraževanja.

Shema 1: Analitični prikaz sestavin izobraževanja in usposabljanja častnikov

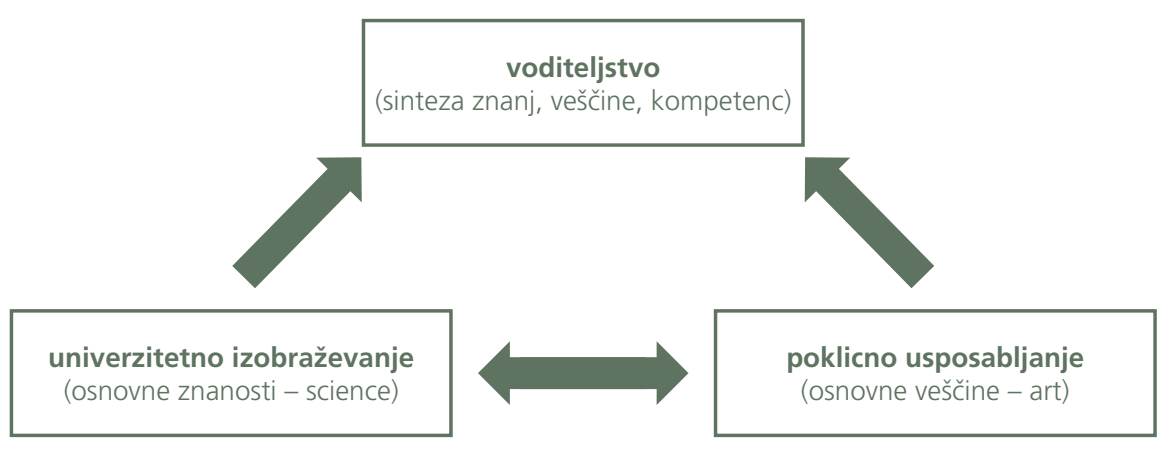

Temeljni sestavini ali stebra, na katerih temelji šolanje častnikov, sta univerzitetno izobraževanje in poklicno usposabljanje. $\mathrm{V}$ različnih razmerjih sta prisotna $\mathrm{V}$ vseh obravnavanih sistemih šolanja ter skupaj zagotavljata potrebne kompetence 
častnikov (shema 2). Kombinacija navedenih dveh elementov kaže kompleksno naravo opravljanja vojaške profesije, ki jo pogosto označujemo z dvojnostjo, izraženo $\mathrm{v}$ znanosti in veščini (angl. science and art). Medtem ko zasidranost v področje znanosti zahteva analitične in konceptualne pristope, so na področju veščine ključni praktični pristopi, kar pomeni, da so za častnike potrebni širše teoretično znanje in analitične sposobnosti, na področju veščine pa sposobnost aplikacije tega znanja $\mathrm{v}$ konkretne uporabne rezultate.

\begin{tabular}{|c|c|c|}
\hline $\begin{array}{r}\text { Shema 2: } \\
\text { Temeline }\end{array}$ & \multicolumn{2}{|c|}{ Izobraževanje in usposabljanje častnikov } \\
\hline $\begin{array}{l}\text { sestavin izobraže- } \\
\text { vanja in usposa- } \\
\text { bljanja častnikov }\end{array}$ & $\begin{array}{l}\text { univerzitetno izobraževanje } \\
\text { (academic education) }\end{array}$ & $\begin{array}{l}\text { poklicno usposabljanje } \\
\text { (vocational training) }\end{array}$ \\
\hline & $\begin{array}{l}\text { - namen: zagotavljanje širšega } \\
\text { teoretičnega znanja in diplome } \\
\text { 1. ali 2. bolonjske stopnje } \\
\text { - izvajalci: univerze, akademije } \\
\text { - vrednotenje s kreditnimi } \\
\text { točkami: da } \\
\end{array}$ & $\begin{array}{l}\text { - } \text { namen: zagotavljanje } \\
\text { specifičnega znanja za dolžnost } \\
\text { v rodu/službi } \\
\text { - izvajalci: centri za usposabljanje } \\
\text { (application schools) } \\
\text { - vrednotenje s kreditnimi }\end{array}$ \\
\hline
\end{tabular}

Ob sicer zelo različnih vsebinah in oblikah temeljnega šolanja častnikov lahko ugotovimo, da je to povsod sestavljeno iz univerzitetnega izobraževanja in poklicnega usposabljanja. Univerzitetno izobraževanje praviloma ni neposredno namenjeno zagotavljanju sposobnosti za opravljanje častniške dolžnosti, temveč zagotavlja širše in bolj abstraktno znanje in častnike tudi usposobi za nadaljnje učenje med kariero. Pogosto se častniki različnih rodov in služb izobražujejo na istih univerzitetnih programih. Konkretno znanje in sposobnosti za opravljanje prve dolžnosti pa častniki pridobijo v različnih oblikah poklicnega usposabljanja.

Univerzitetno izobraževanje obsega programe na področjih, ki so podobna programom civilnih izobraževalnih ustanov (tehniškim in družboslovnim) oziroma zagotavlja širše in bolj teoretično usmerjeno znanje. Zagotavlja tudi kreditne točke in diplomo 1. ali 2. bolonjske stopnje. To izobraževanje večinoma izvajajo obrambne univerze ali vojaške akademije, v nekaterih primerih poteka v sodelovanju s civilnimi institucijami; ponekod, na primer v Veliki Britaniji in Sloveniji, častniki pridobijo univerzitetno izobrazbo v civilnih izobraževalnih ustanovah. Povsod pa sta javno priznana diploma prve ali druge bolonjske stopnje in ustrezen naziv (Bachelor of Arts ali Master of Arts) glede na program, ki ga častniki zaključijo. V tabeli 2 so prikazani temeljni podatki o izvajanju univerzitetnih programov v izbranih državah. ${ }^{10}$

\footnotetext{
${ }^{10}$ Skupaj je bilo v analizo vključenih 23 držav-članic EU, ki izvajajo šolanje častnikov. Ker bi bilo prikazovanje vseh primerov $v$ članku preobsežno, smo izbrali nekaj držav; z izborom želimo predstaviti predvsem različne modele šolanja. Celoten pregled je predstavljen v Paile, 2011, str. 53-225.
} 


\begin{tabular}{|c|c|c|c|}
\hline \multirow{13}{*}{$\begin{array}{r}\text { Tabela 2: } \\
\text { Izbrani primeri } \\
\text { temeljnega } \\
\text { šolanja častnikov } \\
\text { kopenske vojske - } \\
\text { univerzitetni } \\
\text { programi } \\
\text { Vir: Paile, } 2011 .\end{array}$} & Država & Stopnja - trajanje & Nazivi programov \\
\hline & Avstrija & Visoka - 3 leta & Vojaško voditeljstvo \\
\hline & Belgija & Magisterij stroke - 5 let & Družbene in vojaške znanosti, Tehnične znanosti \\
\hline & Bolgarija & Visoka - 5 let $^{11}$ & $\begin{array}{l}\text { Regionalna in nacionalna varnost, Logistika, Upravljanje virov } \\
\text { in tehnologije, Inženirstvo in tehnologija (različnih smeri), } \\
\text { Zaščita prebivalstva ob katastrofah }\end{array}$ \\
\hline & Češka & Visoka - 3 leta & $\begin{array}{l}\text { Vojaški menedžment in ekonomika nacionalne obrambe, } \\
\text { Vojaška tehnologija }\end{array}$ \\
\hline & Italija & Magisterij stroke - 5 let & $\begin{array}{l}\text { Strateške in politične znanosti, Strateške in infrastrukturne } \\
\text { znanosti, Strateške in komunikacijske znanosti, Strateške in } \\
\text { logistične znanosti, Inženirstvo (različnih smeri) })^{12}\end{array}$ \\
\hline & Madžarska & Visoka - 5 let & $\begin{array}{l}\text { Vojaško voditeljstvo, Vojaška ekonomika, Vojaški in varnostni } \\
\text { inženiring }\end{array}$ \\
\hline & Nemčija & $\begin{array}{l}\text { Magisterij } \\
\text { stroke }-4 \text { leta }^{13}\end{array}$ & $\begin{array}{l}\text { Pedagoške znanosti, Ekonomske znanosti, Družbene } \\
\text { znanosti, Inženirstvo (različnih smeri) }\end{array}$ \\
\hline & Nizozemska & Visoka - 4 leta & $\begin{array}{l}\text { Vojaške znanosti, Poslovna in javna uprava, Komunikacije, } \\
\text { Informatika in sistemi kontrole in poveljevanja, Vojaški sistemi } \\
\text { in tehnologija, Civilno inženirstvo }\end{array}$ \\
\hline & Poljska & Visoka - 4 leta & Menedžment, Nacionalna varnost \\
\hline & Slovaška & Visoka - 3 leta & $\begin{array}{l}\text { Strojno inženirstvo, Računalniško inženirstvo, Elektro } \\
\text { inženirstvo, Vojaški menedžment }\end{array}$ \\
\hline & Slovenija & Visoka - 3 ali 4 leta & Različne smeri civilnih fakultet \\
\hline & Velika Britanija & $\begin{array}{l}\text { Visoka (praviloma) - } \\
\text { in } 1 \text { leto poklicnega } \\
\text { usposabljanja }\end{array}$ & Različne smeri civilnih fakultet \\
\hline
\end{tabular}

V državah članicah EU izobraževanje častnikov kopenske vojske poteka na zelo različnih programih. Enoten program za vse častnike ima od prikazanih držav samo Avstrija, sicer pa še Španija, Latvija in Estonija. V vseh drugih državah izvajajo več programov, tako tehničnih kot družboslovnih usmeritev. Skladno s tem častniki po končanem izobraževanju dobijo tudi različne univerzitetne nazive. Programi izobraževanja imajo večinoma 'civilni značaj' in se izvajajo po istih kriterijih kot univerzitetni študij na civilnih fakultetah. Ponekod, na primer na Poljskem, so tovrstni programi odprti tudi za študente, ki se ne šolajo za častnike.

"I Prvo bolonjsko stopnjo (BA) bodoči častniki v nekaterih državah dosežejo šele po petih letih, ker študij združuje akademsko izobraževanje in poklicno usposabljanje.

${ }_{12}$ Najpogosteje so to: strojno inženirstvo, elektro inženirstvo, gradbeno inženirstvo, industrijsko inženirstvo, računalniško inženirstvo in telekomunikacijsko inženirstvo.

${ }_{13}$ V Nemčiji se častniki na prvo dolžnost pripravljajo šest let, ker je univerzitetnemu izobraževanju dodano še temeljno vojaško in poklicno usposabljanje. Univerzitetno izobraževanje poteka na dveh akademijah Zvezne vojske, in sicer v Hamburgu in Münchnu. 
Povsod je univerzitetna izobrazba tudi pogoj za vstop v častniške vrste. Izjema je Velika Britanija, v kateri imajo lahko častniki tudi nižjo stopnjo izobrazbe, vendar spodbujajo študij častnikov in ti večinoma že med kariero dosežejo univerzitetno izobrazbo. Stopnja univerzitetne izobrazbe, ki jo morajo častniki doseči med temeljnim šolanjem, je različna; med prikazanimi primeri vidimo, da je v Belgiji, Italiji in Nemčiji to magisterij stroke, v drugih državah pa visoka izobrazba oziroma prva bolonjska stopnja. Tudi trajanje šolanja se razlikuje, celo takrat, ko gre za doseganje enake stopnje izobrazbe. To je predvsem posledica dejstva, da v nekaterih državah v izvajanje univerzitetnih programov vključujejo poklicno usposabljanje, kar podaljša čas šolanja. Poleg univerzitetnega izobraževanja morajo bodoči častniki praviloma opraviti še temeljno vojaško usposabljanje in poklicno usposabljanje, ki lahko traja od 6 do 24 mesecev; tako da celotno šolanje častnikov traja od 4 do 6 let.

Poklicno usposabljanje je druga sestavina šolanja častnikov. Je praktični vidik tega procesa in bodoče častnike usposablja za opravljanje konkretne dolžnosti, ki jo bodo prevzeli po končanem šolanju. Oblike in načini izvajanja usposabljanja so v posameznih državah še bolj različni kot izvajanje univerzitetnega izobraževanja. Praviloma poteka v institucijah, ki so ločene od univerz ali akademij, ter povezane s specifičnimi rodovi ali službami. To usposabljanje ni v vseh državah ovrednoteno s kreditnimi točkami, torej nima statusa univerzitetnega izobraževanja. Od 23 držav, vključenih $\mathrm{v}$ analizo, jih samo osem priznava kreditne točke. ${ }^{14}$ Poklicno usposabljanje je tudi zelo različno umeščeno v potek šolanja. Ponekod poteka vzporedno z univerzitetnim programom, drugje samo v določenih obdobjih šolskega leta, ponekod pa je umeščeno na konec šolanja. Znatne razlike med državami so tudi glede povezanosti univerzitetnega izobraževanja in poklicnega usposabljanja - ti dve sestavini nekateri razumejo kot popolnoma ločeni, spet drugi pa kot povezani sestavini enotnega procesa. Nabor programov poklicnega usposabljanja je odraz potreb po častnikih $\mathrm{v}$ rodovih in službah kopenske vojske, ki jih država razvija. Najbolj na splošno častnike kopenske vojske umestijo v eno izmed naslednjih oblik usposabljanja: pehota, artilerija, inženirstvo, oklepne in mehanizirane enote, RKBO, informatika in komunikacije, logistika, izvidništvo, zračna obramba in letalstvo kopenske vojske.

Razločevanje med univerzitetnim izobraževanjem in poklicnim usposabljanjem se med državami razlikuje. Ponekod med obema poteka stroga ločnica. Usposabljanje konceptualno ni del univerzitetnega izobraževanja in je tudi časovno ločeno od slednjega. Izvaja se na primer po koncu izobraževanja ali $\mathrm{v}$ posebnih terminih znotraj študijskega leta, na primer v poletnih mesecih ali obdobjih med študijskimi semestri. Usposabljanje je lahko konceptualno integrirano v proces univerzitetnega izobraževanja oziroma časovno vzporedno. Paile (2011, str. 31-2) glede na te razlike modele šolanja klasificira na tri osnovne tipe: sestavini sta organsko ločeni, potekata izmenično oziroma paralelno. Razlike ostajajo tudi glede ovrednotenja posameznih sestavin šolanja s kreditnimi točkami. Medtem ko je univerzitetni program praviloma

${ }^{14}$ Bolgarija, Estonija, Francija, Madžarska, Italija, Latvija, Španija in Švedska. 
povsod vrednoten s kreditnimi točkami, pa v manj kot polovici držav kreditne točke dodeljujejo tudi za poklicno usposabljanje.

Na podlagi prikazane analize lahko strnemo naslednje ugotovitve glede organizacijskih in vsebinskih vidikov šolanja častnikov. Organizacijske rešitve se v državah zelo razlikujejo, kar se kaže $\mathrm{v}$ dolžni šolanja in stopnji pridobljene izobrazbe, različni stopnji sodelovanja s civilnimi institucijami, časovnem zaporedju univerzitetnega izobraževanja in poklicnega usposabljanja ter kreditnem vrednotenju poklicnega usposabljanja. Gledano $\mathrm{z}$ vsebinskega vidika ugotovimo veliko raznolikost univerzitetnih programov in programov poklicnega usposabljanja. Podobnosti se kažejo v zahtevi po univerzitetni izobrazbi častnikov; v konceptualnem ločevanju med univerzitetnim izobraževanjem in poklicnim usposabljanjem; v težnji, da se častnikom zagotovita široko znanje in sposobnost prilagajanja hitro spreminjajočim se zahtevam profesije ter $\mathrm{v}$ približevanju značilnostim javnega univerzitetnega izobraževanja. Večina držav ima večje število različnih programov univerzitetnega izobraževanja, s čimer zagotavljajo ustrezno znanje častnikov za posamezne rodove in službe.

\section{EVROPSKA PRAKSA IN SLOVENSKI MODEL ŠOLANJA ČASTNIKOV}

Čeprav vojske držav članic EU vse več nalog izvajajo v večnacionalnih sestavah in se vojaško sodelovanje med državami povečuje, pa temeljno izobraževanje častnikov ostaja odgovornost in pristojnost držav. Razlike glede vsebin, predvsem pa glede načinov šolanja so precejšnje; vsaka država organizira šolanje, ki najbolj ustreza njenim potrebam, zmogljivostim in družbenemu okolju. Šolanje si povsod prizadevajo prilagoditi vse bolj kompleksnim zahtevam vojaške profesije. Narava vojaške profesije določa vsebino izobraževanja, hkrati pa je izobraževanje eden izmed njenih temeljnih sestavnih elementov. Potočnik (2012, str. 34-5) kot ključne značilnosti, ki predstavljajo temelje sodobne vojaške profesije, navaja odnos zaupanja in službe med vojaškimi profesionalci ter civilno družbo, razvito profesionalno kulturo in etiko, formalno notranjo organiziranost ter vseživljenjsko izobraževanje. Na podlagi izobraževanja se pridobi »ustrezno, tudi abstraktno strokovno znanje, ki je specifično za vojaško profesijo in ga ni v nobeni drugi profesiji. Hkrati ta proces omogoča nastanek ustrezne profesionalne kulture in etike, ki oblikujeta značaj posameznega člana profesije.«

$\mathrm{Ob}$ tem, ko sicer ni enotnega 'evropskega' modela temeljnega šolanja častnikov, pa je vseeno smiselno v Sloveniji uveljavljen model šolanja predstaviti tudi z vidika prakse v evropskih državah. Tudi v Sloveniji je, tako kot drugje v Evropi, za vstop v častniško profesijo zahtevana univerzitetna izobrazba, častniki opravijo študij na različnih programih fakultet $\mathrm{v}$ javnem šolstvu, nato pa to izobraževanje dopolnijo s specifičnim vojaškim poklicnim usposabljanjem za rod ali službo. ${ }^{15}$ Ugotovimo lahko, da slovenski model izstopa predvsem glede oblike oziroma organiziranosti,

\footnotetext{
15 V Sloveniji to usposabljanje poteka po zaključku univerzitetnega študija v Šoli za častnike Slovenske vojske. Program traja eno leto in je usmerjen predvsem v vojaške, veščinsko naravnane vsebine.
} 
saj pri nas nimamo vojaške univerzitetne izobraževalne institucije. Glede na to, da v evropskih državah častniki na vojaških izobraževalnih institucijah pridobivajo univerzitetno izobrazbo na zelo različnih (tehniških in družboslovnih) programih, študij pa se približuje sicer veljavnim standardom v javnem šolstvu, lahko trdimo, da študij na javnih fakultetah v Sloveniji opravlja enako funkcijo kot šolanje na vojaških akademijah oziroma fakultetah v evropskih državah. Razlika je torej predvsem v institucijah, ki izvajajo izobraževanje, manj pa v vsebinah.

V Sloveniji smo se $\mathrm{v}$ zadnjih petindvajsetih letih bolj ukvarjali z razmišljanjem o oblikah temeljnega šolanja častnikov kot z njegovo vsebino. ${ }^{16}$ Ena temeljnih dilem pri tem je, ali ustanoviti vojaško univerzitetno izobraževalno institucijo ${ }^{17}$ ali izobraževati v javnih univerzitetnih ustanovah. Po pregledu izobraževanja častnikov v državah EU lahko ugotovimo, da uveljavljeni slovenski model univerzitetnega izobraževanja častnikov vsebinsko bistveno ne odstopa od uveljavljene prakse v teh državah. Skoraj povsod je namreč mogoče zaslediti odmik od koncepta klasičnih vojaških akademij in vse več podobnosti izobraževanja častnikov s programi v javnem izobraževanju. V Sloveniji zelo verjetno drugačna rešitev od zdaj uveljavljene niti z organizacijskega niti s stroškovnega vidika ne bi bila smotrna. $\mathrm{Ob}$ upoštevanju potreb po zelo različnih programih univerzitetnega šolanja častnikov in nizki letni potrebi po novih častnikih ${ }^{18}$ se postavlja vprašanje smotrnosti institucije, ki bi izvajala študij le za vojaške potrebe. Ne nazadnje je treba upoštevati obstoj pedagoškega in znanstvenoraziskovalnega potenciala, ki je v javnih univerzitetnih institucijah, vojaška institucija pa bi morala tak kader šele pridobiti.

Pri razpravi o šolanju častnikov pri nas se je mogoče opreti tudi na konceptualni model ločevanja med univerzitetnim izobraževanjem in poklicnim usposabljanjem, ki je uporabljen v analizi načinov šolanja častnikov v članicah EU. Na tem področju bo treba v prihodnje poiskati odgovore na več vprašanj. Najprej lahko ugotovimo, da pri šolanju častnikov univerzitetnemu izobraževanju ne namenjamo ustrezne pozornosti, čeprav je pomembna podlaga njihovega šolanja. Ob tem, ko interes za častniški poklic med mladimi, ki končajo univerzitetno izobraževanje, še omogoča pokrivanje potreb SV v količinskem smislu, pa glede strukture naletimo na težave. Kot vidimo v tujini, vojske v svojih izobraževalnih institucijah izvajajo različne programe, ki jih potrebujejo. Pri nas vstop v častniške vrste opredeljujeta najprej interes posameznikov in trg delovne sile, ${ }^{19} \mathrm{v}$ nadaljevanju pa selekcijski izbor za šolo za častnike, pri katerem se preverjajo psihofizične sposobnosti in voditeljski potencial posameznika. Zato smer izobrazbe ni med najpomembnejšimi kriteriji,

\footnotetext{
${ }^{16}$ O tej problematiki smo obširneje pisali v eni izmed prejšnjih številk revije Sodobni vojaški izzivi. Glej Zabukovec in Vegič, 2014.

${ }_{17}$ Obravnavana je bila možnost ustanovitve »vojaške fakultete«. Podrobneje o tem v: Zabukovec in Vegič, 2014, str. 66 .

18 Po ocenah Generalštaba SV bi ob ohranjanju sedanjega obsega vojske potrebovali največ do 35 novih častnikov na leto.

${ }^{19}$ Diplomanti študijskih smeri, ki imajo boljše zaposlitve in karierne možnosti na trgu delovne sile, pogosto niso zainteresirani za zaposlitev $v$ vojski oziroma za častniški poklic.
} 
posledično pa struktura častnikov glede na smer univerzitetne izobrazbe ni ustrezna potrebam. Najbolj zaskrbljujoče je pomanjkanje kandidatov iz tehniških študijskih programov. Glede na pregled potreb, ki ga je pripravil Generalštab SV za obdobje od 2016 do 2021, bi med novimi častniki potrebovali 50 odstotkov takih s tehnično smerjo izobrazbe. Podatki kažejo, da v zadnjih letih SV dosega le približno polovico teh potreb, delež pa se še zmanjšuje. ${ }^{20}$

Med izzive, s katerimi se bo treba spopasti v prihodnje, spada tudi prilagajanje programov na univerzah potrebam vojske. To zdaj, ko se posameznik za častniško profesijo odloča šele po študiju, ni mogoče. Univerzitetno izobraževanje je popolnoma ločeno od potreb vojaške organizacije. Vprašanje je tudi, koliko in kako poleg vsebin, ki so »matične« za posamezne izobraževalne programe, bodočim častnikom že med študijem zagotoviti temeljno znanje s področja vojaške stroke. Danes v času študija bodoči častniki ne dobijo znanja o vojaških zadevah, prvi stik z vojaško stroko in vojaško organizacijo vzpostavijo šele po končanem univerzitetnem študiju. Zato med študijem tudi ni možnosti za »vojaško socializacijo《 in razvoj voditeljskih sposobnosti, kar je mogoče tam, kjer univerzitetno izobraževanje izvajajo na vojaških institucijah. Vse to kaže, da je SV na področju univerzitetnega izobraževanja predvsem v vlogi »uporabnika«, ne pa »preskrbovalca« kadrov.

Za napredek v šolanju častnikov pri nas bo pomembno povečanje sodelovanja in doseganje sinergije med javnimi izobraževalnimi institucijami in vojsko ter skrb za vojaško stroko. Slovenska vojska bo morala natančno opredeliti potrebe in izraziti pričakovanja glede izobraževalnih vsebin, ki jih pričakuje od drugih izobraževalnih institucij. ${ }^{21} \mathrm{~V}$ tesnejšem sodelovanju z institucijami javnega izobraževalnega sistema bi bilo treba predvsem iskati odgovor, kako zagotoviti zelo različne profile kadrov, ki so za vojsko nujni. Usmeriti se je smiselno predvsem na pridobivanje znanj, ki so častnikom potrebna, pa jih znotraj vojaške organizacije ni smotrno razvijati. Pri tem morata biti vodili uporabnost in izbor kakovostnih študijskih programov. ${ }^{22}$ Skrb za razvoj vojaške stroke mora ostati predvsem v pristojnosti SV. Tako vojaška znanost kot veščina se razvijata $v$ tesnem stiku s prakso, zato njunega razvoja ni mogoče prepustiti javnim izobraževalnim ustanovam. Predvsem morajo v domeni SV ostati vsebine poklicnega usposabljanja častnikov, torej tiste, ki so ključne za opravljanje konkretnega dela.

V takšni »delitvi dela« med javnimi izobraževalnimi ustanovami in SV je mogoče rešiti tudi vprašanje, koliko je v izobraževanju častnikov treba upoštevati univerzitetna merila. V Sloveniji smo se v preteklosti srečevali predvsem z dilemo

${ }^{20}$ Leta 2012 je bilo v generaciji novo izšolanih častnikov še 42 odstotkov takih s tehnično izobrazbo, leta 2014 je takih 24 odstotkov, leta 2016 pa 26 odstotkov. Med tistimi, ki bodo šolanje začeli leta 2017, pa le 18 odstotkov. V preostalem deležu šolajočih se častnikov je največ diplomantov varstvoslovja, sledijo diplomanti obramboslovja, logistike in drugih družboslovnih ter poslovnih in upravnih ved.

${ }^{21}$ Zavedati se je treba, da samo to ne bo dovolj, temveč bo treba izvajati tudi ustrezno kadrovsko politiko, ki bo zagotovila zadosten interes za študij na programih, ki so za vojsko pomembni.

${ }^{22} Z$ naraščanjem števila visokošolskih izobraževalnih institucij v Sloveniji v zadnjih dveh desetletjih je prišlo tudi do povečevanja razlik glede kakovosti izvajanja študijskih programov. 
glede potrebe po učiteljih, habilitiranih po visokošolskih merilih. ${ }^{23}$ To je potrebno pri tistih vsebinah, ki so podlaga za pridobitev diplome, torej v programih v javnih izobraževalnih ustanovah. Ni pa smiselno pri takih kriterijih vztrajati pri poklicnem usposabljanju častnikov, torej pri programu, ki se izvaja v Šoli za častnike.

Sklep Primerjavo med slovenskim modelom in evropsko prakso temeljnega šolanja častnikov lahko sklenemo s priporočilom, da je smiselno ločevati med vsebinskimi in organizacijskimi vidiki tega procesa. Vsebino določajo predvsem potrebe častniške profesije, ki so na evropski ravni precej podobne, vse večji obseg delovanja vojsk v večnacionalnih okvirjih pa bo določal nadaljnje vsebinsko približevanje. Organizacijske oblike šolanja so zelo različne in odvisne od potreb, zmožnosti, tradicije in drugih dejavnikov, značilnih za vsako državo. Prihodnji razvoj šolanja častnikov pri nas bo moral slediti praksi tujih držav predvsem na vsebinskem področju, način organiziranja pa je smiselno prilagoditi lastnim potrebam in zmožnostim.

Kljub vsebinskim in predvsem organizacijskim razlikam $\mathrm{v}$ temeljnem šolanju častnikov, ki jih pokaže primerjava na evropski ravni, je povsod temeljno vodilo prilagajanje šolanja potrebam vojaške profesije, zato je treba v ospredje razmislekov o šolanju častnikov postaviti razumevanje vojaške profesije. Znanje vojaškega profesionalca pri nas je sinteza znanja, ki ga posameznik pridobi v javnih izobraževalnih ustanovah, in znanja, ki ga pridobi na šolanju znotraj SV. Razvoj in posredovanje vojaškostrokovnega znanja, ki pomembno določa kakovost vojaških profesionalcev, je v domeni SV. Njene vojaške izobraževalne institucije niso odgovorne samo za veščinsko usposabljanje, temveč tudi za razvoj vojaške znanosti. Spremembe na področju razumevanja vojaškega izobraževanja kažejo, da je treba že na nižjih ravneh šolanja častnike opremiti s širšim in bolj abstraktnim teoretičnim znanjem. Temeljnega šolanja častnikov v SV torej ne smemo razumeti le kot pripravo na opravljanje prve častniške dolžnosti, temveč kot izobraževalni proces, ki bo omogočal profesionalni razvoj tudi v nadaljnji karieri častnika in zagotovil podlage za nadaljevalno karierno izobraževanje.

\section{Literatura}

1. Doktrina vojaškega izobraževanja in usposabljanja, 2013. Slovenska vojska.

2. Education and Training Directive - Bi-SC 75-2, 2013. NATO.

3. Foot, P., 2006. Military Education and the Transformation of the Canadian Forces. Canadian Military Journal. www.journal.forces.gc.ca/vo7/no1/doc/transfor-01-eng.pdf (6. 7. 2016)

4. International Military and Defence Encyclopedia, 1993. Washington, Brassey's.

\footnotetext{
${ }^{23}$ Na sploh so merila glede izvajalcev vojaškega izobraževanja in usposabljanja (VIU) precej ohlapno opredeljena. Ločevanja med univerzitetnim izobraževanjem in poklicnim usposabljanjem (kot smo ga predstavili v prispevku) slovenski normativni akti, ki obravnavajo VIU, ne poznajo. V 20. členu Zakona o službi v SV je zapisano, da »organizacija in izvajanje vojaškega izobraževanja poteka v skladu z Zakonom o obrambi in predpisi, ki urejajo srednje poklicno in strokovno izobraževanje ter višje strokovno in visokošolsko izobraževanje ter podiplomski študij. «Pri tem ni jasno opredeljeno, kaj je vojaško izobraževanje niti v katerih primerih bi bilo treba te predpise upoštevati. Tako zapisane zahteve omogočajo različne interpretacije.
} 
5. Johnson-Freese, J., 2013. Prerequisites to Transformative Joint Professional Military Education. VWells, L., Hailes T., C., Davies M., C., (ur.) Changing Mindsets to Transform Security: Leader Development for an Unpredictable and Complex World. Washington, National Defense University.

6. Kotnik, I., 2012. Profesionalizacija slovenske vojske-cilj ali pot. Sodobni vojaški izzivi, $14 / 1$.

7. Kramar, M., 1996. Vojaška didaktika. Ljubljana, Ministrstvo za obrambo.

8. McCausland J. D., Martin, G. F., 2001. Transforming Strategic Leader Education for the 21st-Century Army. Parameters, Autumn 2001.

9. Munnik, T,. 2012. Teaching War. V Lindley-French, J., Boyer, Y. (eds.). The Oxford Handbook of War.

10. Paile, S., 2011. Compendium of the European Military Officers Basic Education. orbi.ulg. ac.be/bitstream/2268/100625/1/Compendium.pdf (21. 9. 2016).

11. Potočnik, V., 2012. Vojaška profesija in profesionalni častnik včeraj, danes in jutri. Sodobni vojaški izzivi, 14/1.

12. U.S. Profesional Military Education Policy, 2015.

13. https://archive.org/stream/Officer-Professional-Military-Education-Policy-29-May-2015/ Officer\%20Professional\%20Military\%20Education\%20Policy,\%2029\%20May\%20 2015_djvu.txt

14. Vojaška doktrina, 2006. Poveljstvo za doktrino, razvoj, izobraževanje in usposabljanje. Ljubljana.

15. Zabukovec, S., Vegič, V., 2014. Izobraževanje častnikov-od razprav o organiziranosti k razmisleku o vsebinah. Sodobni vojaški izzivi, 16/2.

16. Žabkar A., Svete, U., 2008. Šolanje vojaških profesionalcev med tradicionalnimi izhodišči in (post)modernimi izzivi. Bilten slovenske vojske, 10/1. 